\title{
Investigation of the Effect of Grain Size, Flow Rate and Diffuser Design on the CAWST Biosand Filter Performance
}

\author{
Colleen C.V. Chan \\ Faculty, Department of Civil Engineering \\ School of Construction and Environment \\ British Columbia Institute of Technology \\ colleen_chan@bcit.ca \\ Darien Cusworth \\ Undergraduate, Department of Civil Engineering \\ School of Construction and Environment \\ British Columbia Institute of Technology
}

\author{
Kyle Neufeld \\ Undergraduate, Department of Civil Engineering \\ School of Construction and Environment \\ British Columbia Institute of Technology \\ Stevan Gavrilovic \\ Undergraduate, Department of Civil Engineering \\ School of Construction and Environment \\ British Columbia Institute of Technology
}

\author{
Tommy Ngai \\ Director of Research Learning \\ Center for Affordable Water and Sanitation Technology
}

\begin{abstract}
The effects of grain size, hydraulic loading rate, batch residence time and diffuser design on the performance of the CAWST version 10 biosand filter was investigated. Two types of sand gradations were prepared - fine sand $(\mathrm{ES}=0.20, \mathrm{UC}=\mathbf{2 . 3})$ and a coarse sand $(\mathrm{ES}=\mathbf{0 . 2 5}, \mathrm{UC}=\mathbf{2 . 9})$. The fine sand and coarse grains resulted in initial hydraulic loading rates of $0.3 \mathrm{~m}^{3} / \mathrm{m}^{2}$ min and $0.75 \mathrm{~m}^{3} / \mathrm{m}^{2} \mathrm{~min}$, respectively. Flow restrictions were installed on 2 coarse grain filters such that their initial hydraulic loading rates were $0.3 \mathrm{~m}^{3} / \mathrm{m}^{2}$ min. For the range of grain size and flow rates investigated in this paper, coarse grain size leads to lower bacterial removal efficiencies compared to the fine grain size. The addition of flow restrictions on filters with coarse grain size did not result in improvement in bacterial removal efficiencies. Two different diffuser designs were also investigated (hole size of $1 / 8$ inch or $3.2 \mathrm{~mm}$ and 0.5 inch or $12.7 \mathrm{~mm}$ spacing, hole size of 3/16 inch or $9.5 \mathrm{~mm}$ and 0.5 inch or $12.7 \mathrm{~mm}$ spacing). These filters were compared to the standard design of CAWST version 10 filter, i.e. control filter, which has a hole size of 1/8 inch $(3.2 \mathrm{~mm})$ and 1 inch $(25.4 \mathrm{~mm})$ spacing. Diffuser design was found to have an effect on the bacterial removal efficiency. The two diffuser investigated (smaller hole size, tighter spacing) resulted in lower bacterial removal efficiencies, compared to the CAWST specified diffuser design. Batch residence time was found to have a significant effect on bacterial removal. The deficiencies caused by diffuser design, coarse grain size were compensated by a higher batch residence time.
\end{abstract}

Index Terms: Batch residence time, biosand filter, diffuser design, grain size, hydraulic loading rate 


\section{INTRODUCTION}

In 2010, the United Nations General Assembly recognized access to clean drinking water and sanitation is a basic human right, and is a prerequisite to the realization of all other human rights. But according to the World Health Organization, 9\% of the world's population living in developing countries is still without access to clean drinking water ${ }^{1}$. Traditional centralized, large scale water treatment projects have been ineffective in the delivery of clean water to a large percentage of the population in developing countries due to the complexities associated with the planning and the construction of new infrastructure, and the potential of contamination during distribution and handling. Additionally, most of those without access to safe water live in rural areas where traditional centralized treatment and distribution networks become cost prohibitive for governments and donors ${ }^{2}$, and are without access to trained personnel for the necessary operation and maintenance of the infrastructures. To address the above issues with centralized treatment systems, recent focus has been on the use of point - of - use, or household treatment technologies, which are decentralized technologies used for the provision of clean water in vulnerable communities in developing countries ${ }^{3}$. Using point-of-use technologies, a family is responsible for treating their own water relatively cheaply instead of relying on centralized treatment technologies at the community or municipal scale.

The biosand filter is a household point-of-use water treatment system, and has been identified as a sustainable and suitable water treatment technology in rural remote areas in developing countries ${ }^{3}$. It is a modified intermittently operated slow sand filter capable of filtering pathogens, suspended solids and decreasing turbidity levels through physical, physicochemical and biological processes. Studies from laboratory and field investigations on the efficacy of biosand filters have reported various degrees of pathogen removal ( 1 to $2 \log$ bacteria reduction, 4 to $7 \log$ viruses reduction, and 4 to $5 \log$ protozoa reduction ${ }^{4-11}$ ). The reduction in the amount of pathogens in drinking water greatly increases the health of the people using the biosand filter. Field studies have shown that families that actively use a biosand filter experience a reduction in diarrhea ${ }^{8,12,13}$, which is one of the leading causes of death in children of developing countries ${ }^{14}$. Turbidity removal have been also reported to be greater than $85 \%$. improvement in the appearance, taste, and odour of the filtered water are important factors leading to the high rate of user acceptability and sustained use of the biosand filter technology ${ }^{16}$. In addition to improvements in water quality, a biosand filter is relatively cheap (US\$15-\$40), constructed using locally available resources, durable, and provide business opportunities for the communities involved $^{16}$. There are many types of biosand filters being used worldwide - some are constructed out of plastic containers (i.e. Davnor Biosand, Hydraid, PVC pipe filter) and some are constructed using concrete. It has been estimated that by the end of 2013, 650,000 biosand filters of all types have been distributed in 55 countries $^{17}$.

\section{CAWST BIOSAND FILTER}

A CAWST biosand filter stands approximately $1 \mathrm{~m}$ tall and is a rectangular box in shape, with $0.3 \mathrm{~m}$ wide sides, as shown in Figure 1. The filter works solely by gravity, with no mechanical pump or electricity required. 


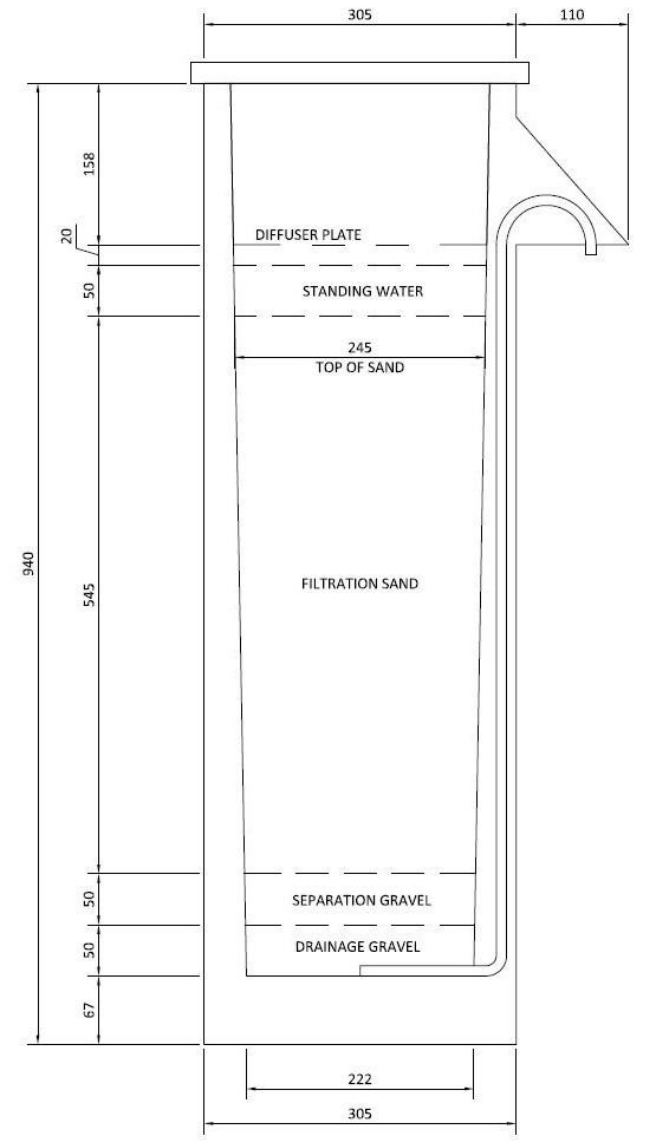

(a)

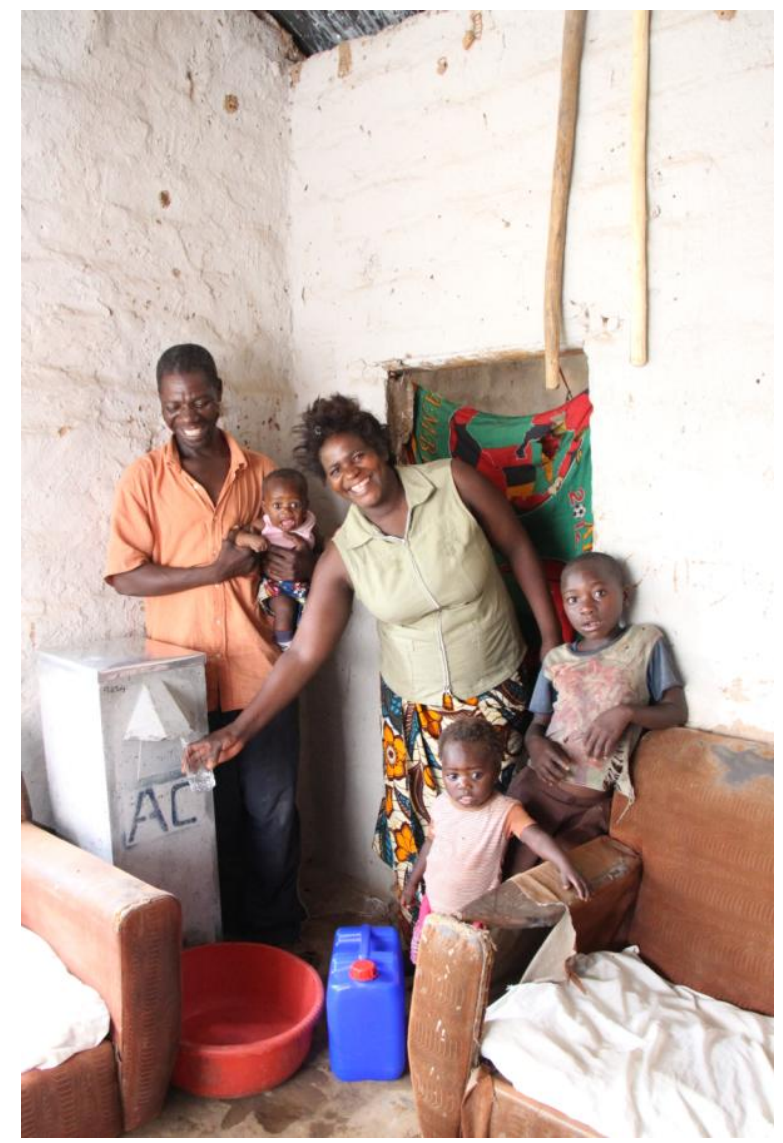

(b)

FIGURE 1

(a) A SCHEMATIC OF THE CAWST VERSION 10 BIOSAND FILTER (b) A CONCRETE BIOSAND FILTER USED BY A FAMILY IN ZAMBIA

There are several different layers in the filter, consisting of sand, different sized gravel, and a microbiological layer known as a "schmutzdecke", or the biolayer. Predation of pathogens in the biolayer is one of the mechanisms of pathogen removal in the biolayer, therefore the protection of the biolayer is a key consideration in the design and operation of the biosand filter. A diffuser box is placed above the biosand filter, and is used to dissipate the kinetic energy of the water entering the filter to minimize disturbances to the biolayer below. The diffuser box is constructed using metal or plastic plate that has a uniform distribution of small, drilled holes to allow the poured water to percolate through, as shown in Figure 2. In addition to the diffuser box, $5 \mathrm{~cm}$ of standing water depth above the sand also limits water disturbance to the biolayer by absorbing the energy of water upon impact. Biolayer disturbances have been shown to reduce bacterial removal efficiency. Vanderzwaag et al. ${ }^{10}$ examined the effect of standing water depth above the biolayer on bacterial removal, and found that the higher standing water depth (up to $20 \mathrm{~cm}$ ) results in better bacterial removal compared to lower standing depth. Improved 
performance of filters with a higher standing water depth can be attributed to reduction in disturbances to the biolayer, compared with filters with a lower standing water depth. However, a high standing water depth must be balanced with the need for oxygen transfer across the water depth to support the biological metabolism of organics contaminants in the biolayer ${ }^{9}$. Too high of a water depth may limit the oxygen transfer to the biolayer, which may adversely affect filter performance.

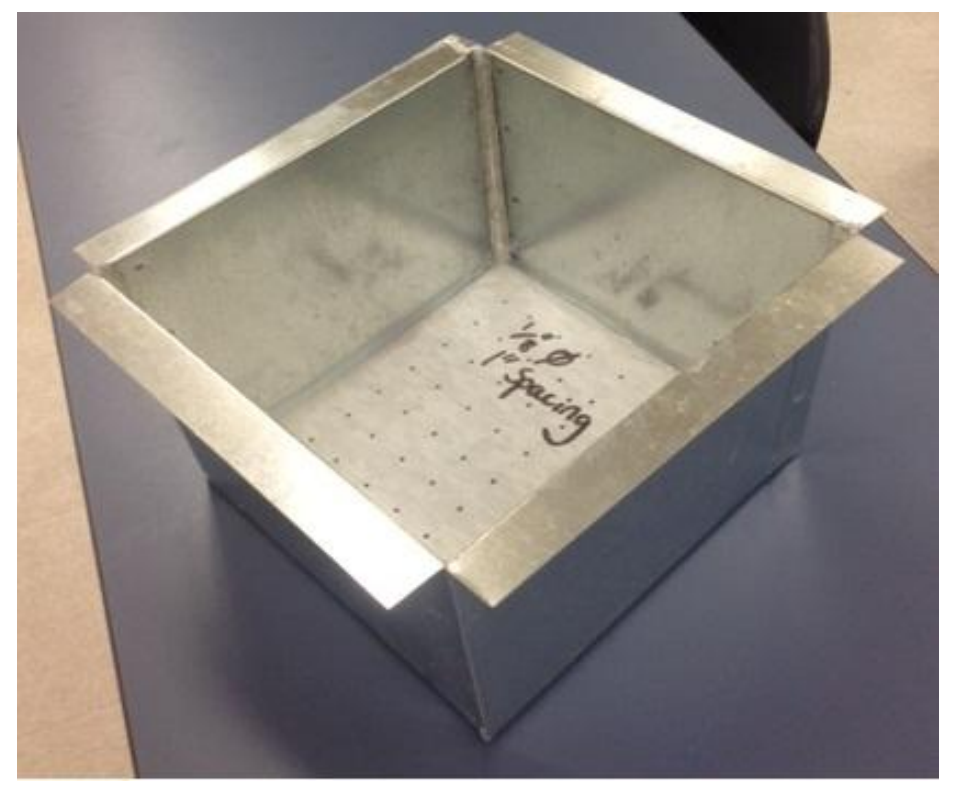

FIGURE 2

\section{A CAWST SPECIFIED DIFFUSER BOX (WITH 1/8" HOLE AND 1" SPACING)}

Depending on the dosing source water quality, the growth of the biolayer generally takes days or weeks to mature and stabilize 4 . As the filter is dosed with water, pathogens in the contaminated water are removed through predation and/or degradation upon contact with the biolayer $^{18}$. Beneath the biolayer, one layer of sand and two layers of gravel fill the cavity of the biosand filter. The sand layer is the largest layer by volume and consists of fine sand. Proper selection of the type of sand is important in reducing pathogens in the filtered water. In general, fine sand is better than coarse sand. The high surface area to volume ratio of a fine sand allows increased adsorption of pathogens onto the sand grain or the biofilm surrounding the grain ${ }^{19}$, compared to the coarse grain. Additionally, the pore space between individual grains is small for fine sand, thus increasing the mechanical sieving and trapping efficiency of pathogens ${ }^{6}$. Towards the bottom of the sand layer, a combination of oxygen depletion and limited food source result in pathogens starvation and death. The final layers of the biosand filter are gravel layers, one consisting of separation gravel and below that, the drainage gravel. The separation gravel layer supports the fine sand layer above and helps to prevent the sand from filtering down into a collection outlet tube. The drainage gravel is constructed with larger gravel rocks and supports the separation layer above. The filtered water at the bottom of the filter is collected and delivered to the collection outlet tube, which is located about $5 \mathrm{~cm}$ above the top of the sand layer to allow for $5 \mathrm{~cm}$ of standing water above the biolayer. 
The efficiency of pathogen removal is dependent on the operating conditions and the design parameters of the filter (i.e. batch residence time, grain size, and hydraulic loading rate). Batch residence time is defined by the how long the influent water remains in the filter before the next cycle of filtration. In general, a higher batch residence time results in better pathogen removal, compared to a lower batch residence time ${ }^{6,20}$. CAWST recommends a minimum batch residence time of 6 hours between each dosing cycle. Using fine grains has been observed to result in better pathogen removal compared to using coarse grains ${ }^{6}$. The high surface area to volume ratio of fine sand allows increased adsorption of pathogens onto the sand grains or the biofilm surrounding the grains ${ }^{19}$, compared to coarse grains. Additionally, the pore space between individual grains is smaller for fine sand, thus increasing the mechanical sieving and trapping efficiency of pathogens ${ }^{6}$.

Hydraulic loading rate, defined as the ratio of volumetric flow rate and the filtration cross-sectional area has been reported to have varying degrees of improvement on bacteria efficiencies ${ }^{6,7,10,21}$. It is hypothesized that a slower hydraulic loading rate leads to increased contact time between the bacteria and the surface of the sand grain and the biolayer. This leads to increased bacteria removal through bacterial adsorption and predation in the biolayer ${ }^{6,10}$. Additionally, a lower hydraulic loading rate may also result in reduced shearing of the biofilm surrounding the sand grain, thus maintaining the integrity of the biofilm and aids in further maturation and development of the biofilm. For the version 10 filter, CAWST recommends a maximum hydraulic loading rate of $0.4 \mathrm{~m}^{3} / \mathrm{m}^{2} \mathrm{hr}$ (corresponding to a maximum flow rate of $0.4 \mathrm{~L} / \mathrm{min}$ ) to ensure proper bacterial removal during filtration.

Some of the ways to control the hydraulic loading rate include (1) changing the hydraulic head of the water above the sand, (2) changing the depth of the sand bed, (3) changing the filtration sand gradation (i.e. coarse grain results in higher flow rate compared to fine sand), or (4) installing a flow restriction at the end of the effluent collection tube. Current CAWST version 10 filters specify a sand gradation with an effective size $<0.2$ and uniformity coefficient $<2.3$. This, along with a 0.25 inch (internal diameter) collection outlet tube yields a hydraulic loading rate of less than $0.4 \mathrm{~L} / \mathrm{m}^{2} \mathrm{hr}$. In practice, achieving the CAWST specified sand gradation is often a labour intensive sand preparation process and requires specific types of sieves for the sand preparation. A recent study found one of the commonly reported problems with the biosand filter is that "the sand for the BSF was not properly selected and prepared, resulting in too high of a flow rate, which compromises the filter's performance". Of the users of the biosand filters surveyed, "only $52 \%$ of the BSFs had correctly installed sand"16.

In places where the sand gradation specified by CAWST cannot be met (i.e. a coarser sand is used instead of the finer sand specified), a practical solution may be to install a flow restriction at the outlet tube such that the hydraulic loading rate criteria of less than $0.4 \mathrm{~L} / \mathrm{m}^{2} \mathrm{hr}$ is met. Although previous studies have shown either the effects of sand grain size or hydraulic loading rate on filter performance, however, it is not clear what effects the combination of using coarse sand and installing flow restriction valves will have on the filter's bacterial removal efficiencies, and whether the installation of a flow restriction can be justified.

Another practical question arises as to whether the design of the filter diffuser will have an impact on water quality. As mentioned before, the diffuser functions as an energy dissipator of the poured water, thus minimizing disturbances to the biolayer. Current CAWST version 10 filters recommend a diffuser with $1 / 8$ inch circular holes with 1 inch spacing. It is not clear if 
deviation from the CAWST diffuser specifications will have an impact on bacterial removal efficiency.

The questions above lead to the objectives of this research paper, which are to provide recommendations for the CAWST filters on (1) whether the installation of a flow restriction can be justified, and (2) whether different diffuser designs will impact the filtration bacterial removal efficiencies. The experimental investigations in this paper were performed using CAWST version 10 filters. To achieve object 1, bacteria removal were measured in filters installed with coarser sand than those specified by CAWST, and installed with flow restriction valves. These bacterial values were compared with a CAWST filter. To achieve objective 2, bacteria removal in filters installed with diffuser configurations different than those specified by CAWST were compared with a CAWST filter. The combined impacts of filtration hydraulic loading rate and filter sand size, batch residence time and diffuser design on filtered water quality were examined. The research project described in this paper was conducted by undergraduate Civil Engineering students through a combination of an industry project course and an applied research project course.

\section{Filter Sand Design}

\section{EQUIPMENT AND MATERIALS}

In total, six CAWST version 10 concrete biosand filters were constructed. Crushed rock was used as the primary filtration media for all six filters. The sand was obtained from Allard Sand and Gravel located in Coquitlam, British Columbia. Over $800 \mathrm{~L}$ of sand was washed, dried, and sieved for all 6 filters. Two types of sand gradations were prepared - fine sand of $\mathrm{D}_{100}<0.71$ $\mathrm{mm}$ and a coarse sand of $\mathrm{D}_{100}<1.68 \mathrm{~mm}$. ( $\mathrm{D}_{100}$ is defined by one hundred percent of sand passing through a sieve with a specified sieve opening). The $\mathrm{D}_{100}<0.71 \mathrm{~mm}$ sand are within limits of CAWST recommendations. The $\mathrm{D}_{100}<1.68 \mathrm{~mm}$ was chosen such that the initial hydraulic rate through the filter is approximately twice of the maximum specified by CAWST (maximum specified by CAWST is $0.4 \mathrm{~m}^{3} / \mathrm{m}^{2} \mathrm{hr}$ ). In this paper the $\mathrm{D}_{100}<0.71 \mathrm{~mm}$ sand is referred as the fine sand, the $\mathrm{D}_{100}<1.68 \mathrm{~mm}$ is referred as coarse sand. The sieve analyses of the fine sand and the coarse sand, and their respective effective sizes and uniformity coefficients are shown in Table 1a, Table $1 \mathrm{~b}$ and Table 2. Beneath the sand layer were the drainage and separation gravel obtained from crushed granite. The separation gravel was sieved using 1-6 mm diameter sizes and the drainage gravel was sieved using 6-12 $\mathrm{mm}$ diameter sizes, as specified by CAWST.

TABLE 1a

SIEVE ANALYSIS FOR THE COARSE SAND $\left(\mathrm{D}_{100}<1.68 \mathrm{MM}\right)$

\begin{tabular}{cccc}
\hline Sieve Number & $\begin{array}{c}\text { Mesh Opening } \\
(\mathbf{m m})\end{array}$ & $\begin{array}{c}\text { Percent Retained } \\
(\boldsymbol{\%})\end{array}$ & $\begin{array}{c}\text { Percent Passing } \\
(\boldsymbol{\%})\end{array}$ \\
\hline 12 & 1.68 & 0 & 100 \\
16 & 1.18 & 12 & 88 \\
20 & 0.85 & 18.4 & 69.6 \\
30 & 0.60 & 19.2 & 50.4 \\
60 & 0.25 & 40 & 10.4 \\
140 & 0.11 & 9.6 & 0.8 \\
PAN & $<0.11$ & 0.8 & 0 \\
\hline
\end{tabular}


TABLE 1b

SIEVE ANALYSIS FOR THE FINE SAND $\left(\mathrm{D}_{100}<0.71 \mathrm{MM}\right)$

\begin{tabular}{cccc}
\hline Sieve Number & $\begin{array}{c}\text { Mesh Opening } \\
(\mathbf{m m})\end{array}$ & $\begin{array}{c}\text { Percent Retained } \\
(\boldsymbol{\%})\end{array}$ & $\begin{array}{c}\text { Percent Passing } \\
(\boldsymbol{\%})\end{array}$ \\
\hline 24 & 0.71 & 0 & 100 \\
30 & 0.6 & 12.8 & 87.2 \\
40 & 0.425 & 33.2 & 54 \\
60 & 0.250 & 37.6 & 16.4 \\
100 & 0.15 & 12.4 & 4.0 \\
140 & 0.106 & 4.0 & 0 \\
PAN & $<0.106$ & 0 & 0 \\
\hline
\end{tabular}

TABLE 2

EFFECTIVE SIZE (ES) AND UNIFORMITY COEFFICIENT (UC) OF SAND GRADATIONS

\begin{tabular}{lll}
\hline Sand Gradation & ES & UC \\
\hline $\mathrm{D}_{100}<1.68 \mathrm{~mm}$ & 0.25 & 2.9 \\
$\mathrm{D}_{100}<0.71 \mathrm{~mm}$ & 0.20 & 2.3 \\
\hline
\end{tabular}

The flow rates of each filter with different sand gradations were tested according to CAWST's recommended procedure. Each filter was filled to the maximum before the initial flow was recorded. The fine sand used in the control filter CAWST filter and the filters used for diffuser design experiments resulted in an initial flow rate of $0.3 \mathrm{~L} / \mathrm{min}$ (hydraulic loading rate of $0.3 \mathrm{~m}^{3} / \mathrm{m}^{2} \mathrm{hr}$ ). The coarse sand resulted in an initial flow rate of $0.75 \mathrm{~L} / \mathrm{min}$ (hydraulic loading rate of $0.75 \mathrm{~m}^{3} / \mathrm{m}^{2} \mathrm{hr}$ ). The CAWST recommended maximum flow rate is $0.4 \mathrm{~L} / \mathrm{min}$ (hydraulic loading rate of $0.4 \mathrm{~m}^{3} / \mathrm{m}^{2} \mathrm{hr}$ ).

\section{Filter Design}

Six filters, with various sand size, diffuser designs and flow restrictions were designed. Table 2 shows the design specifications for the six filters. The CAWST filter was the control filter as per CAWST design specifications ${ }^{22}$. The Coarse Grain-B filter was filled with coarse sand with no flow restriction, resulting in an initial flow rate of $0.75 \mathrm{~L} / \mathrm{min}$, measured at maximum head. The Coarse Grain-A1 and Coarse Grain-A2 filters were filled with coarse sand, and with flow restriction valves installed at the outlet tube, resulting in an initial flow rate of $0.30 \mathrm{~L} / \mathrm{min}$, measured at maximum head. The location of the flow restriction valves on the outlet tube were adjusted to ensure there was $5 \mathrm{~cm}$ of standing water above the filter. All coarse grain filters used the same diffuser box as the CAWST control filter.

The Diffuser-A and Diffuser-B filters were similar to the CAWST filter, but installed with different diffuser boxes after Day 26 of experiment. Before Day 26, Diffuser A and B filters were fitted with the CAWST specified diffuser box (1/8 inch, 1 inch spacing). After Day 26 , Diffuser-A was changed to a diffuser hole size of $1 / 8$ inch and 0.5 inch spacing, Diffuser-B was changed to a diffuser hole size of $3 / 16$ inch and 0.5 inch spacing. 
TABLE 2

DESIGN SPECIFICATIONS FOR THE SIX FILTERS CONSIDERED. HIGHLIGHTED CELLS SHOW DEVIATIONS FROM CAWST SPECIFICATION

\begin{tabular}{|l|l|l|l|l|c|}
\hline \multirow{2}{*}{ Filter } & \multicolumn{2}{|l|}{ Diffuser Design } & Sand Size & $\begin{array}{l}\text { Flow } \\
\text { Restriction } \\
\text { Valve }\end{array}$ & $\begin{array}{l}\text { Initial Flow } \\
\text { Rate } \\
\text { (L/min) }\end{array}$ \\
\cline { 2 - 6 } & $\begin{array}{l}\text { Hole Size } \\
\text { (inches) }\end{array}$ & $\begin{array}{l}\text { Spacing } \\
\text { (inches) }\end{array}$ & & No & 0.3 \\
\hline Control & $1 / 8$ & 1 & Fine & Yes & 0.3 \\
\hline Coarse Grain-A1 & $1 / 8$ & 1 & Coarse & Yes & 0.3 \\
\hline Coarse Grain-A2 & $1 / 8$ & 1 & Coarse & No & 0.75 \\
\hline Coarse Grain- B & $1 / 8$ & 1 & Coarse & No & 0.3 \\
\hline Diffuser-A (<Day 26) & $1 / 8$ & 1 & Fine & No & 0.3 \\
\hline Diffuser-A (> Day 26) & $1 / 8$ & 0.5 & Fine & No & 0.3 \\
\hline Diffuser-B (< Day 26) & $1 / 8$ & 1 & Fine & No & 0.3 \\
\hline Diffuser-B (> Day 26) & $3 / 16$ & 0.5 & Fine & & \\
\hline
\end{tabular}

It is noted that the addition of diffusers A and B is not expected to significantly impact filter flow rate (and corresponding hydraulic loading rate). Since the filters were dosed a total volume of 12 $\mathrm{L}$ at each dosing cycle, all $12 \mathrm{~L}$ of water immediately filled the space above the sand layer, and as such the hydraulic head of the water above the sand layer remained the same for filters installed with Diffusers A and B.

\section{Water Distribution System}

The water distribution system was designed to deliver $12 \mathrm{~L}$ of contaminated water to each of the six filters shown below in Figure 3. The gravity-feed system consisted of a $200 \mathrm{~L}$ reservoir, a direct-acting solenoid valve, and $3 / 4$ inch PVC piping. The system was controlled by a standard irrigation timer which delivered water simultaneously to each filter twice a day. During each dosing, the water distribution system simulated the slow pouring of water in single doses. The automated system allowed two watering cycles before the reservoir needed replenishment. An advantage of using a reservoir is that the influent water for the filters was well mixed which ensured that each filter received the same quality of source water for dosing. 


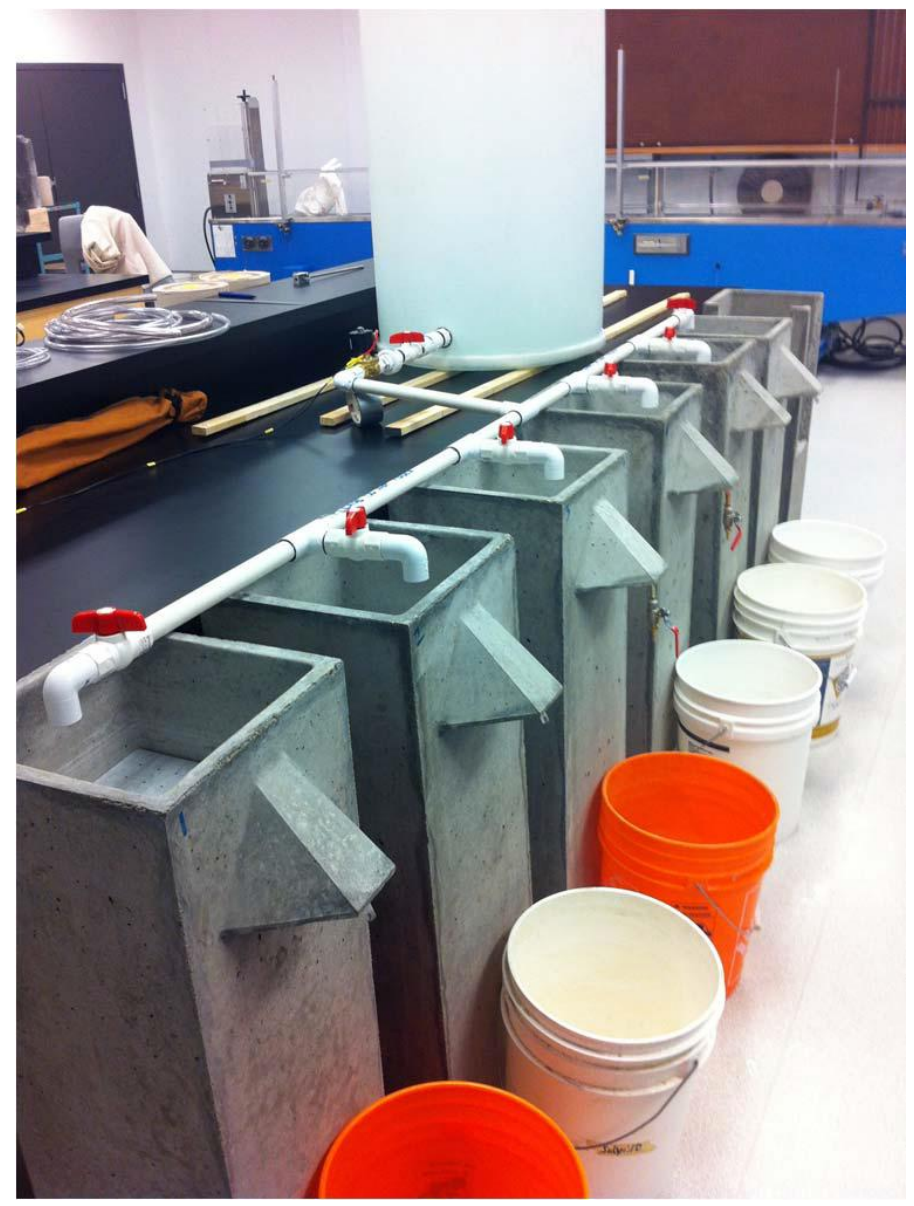

FIGURE 3

THE WATER DISTRIBUTION FOR THE SIX FILTERS

\section{Source Water and Filter Dosing Plan}

Water from Guichon Creek (City of Burnaby, Canada) was used as the source water for dosing the filters. Water was collected twice daily, in the morning (9:00 am dose cycle) and in the afternoon (3:30 pm dose cycle) to dose the filters. Each filter was dosed 12 L of water per dose, resulting in a total of $24 \mathrm{~L}$ of influent per filter, per day. A total of $72 \mathrm{~L}$ of creek influent was collected during each dosing cycle, resulting in a total of $144 \mathrm{~L}$ of water collected daily. The automatic irrigation system was used to distribute the water to the filters as per the weekly plan.

In order to provide sufficient pressure to deliver the water through the water distribution system to each filter, a certain height of water in the storage tank needed to be maintained. This translated to an initial volume of $150 \mathrm{~L}$ of water required in the storage tank during each dosing cycle to deliver water through the distribution system. After the delivery of $72 \mathrm{~L}$ of water to the filters during the dosing cycle, there was approximately $78 \mathrm{~L}$ of water remaining in the storage tank. This remaining water was blended with $72 \mathrm{~L}$ of influent water collected from the creek for the next dosing cycle. The blended water in the storage tank was stored for at least 1 hour prior to dosing each filters, such that the temperature of the filter dosing water approached that of room temperature. 


\section{Water Quality Tests}

Water quality testing of the creek source water and the filtered effluent water was conducted two times a week (every Monday and Thursday at 3:30 pm). A total of 36 samples (18 days of testing, 2 repeat samples per test) were collected over a period of 64 days from February to April 2014. Water turbidity was measured using the HACH 2100Q Portable Turbidity Meter. Total coliform and E.coli were enumerated using the membrane filtration technique ${ }^{23}$ with the $\mathrm{m}$ ColiBlue24 broth. All samples were incubated at $35 \pm 0.5{ }^{\circ} \mathrm{C}$ for 24 hours. For each test, two repeat samples were collected and tested. All effluent samples from each filter were collected simultaneously 5 minutes after dosing water from the water distribution system stopped flowing (which was equivalent to approximately 10 minutes since the effluent water started flowing).

The comparison of bacteria removal among the six filters investigated was represented by the total coliform and E. coli count of the effluent samples, collected at 3:30 pm. Since all filters were dosed with the influent creek water from the same batch storage tank, a comparison of the total coliform and E. coli count in the filter effluent provides a direct comparison of the performance between each filter (i.e. a lower filter effluent total coliform count represents better bacterial removal compared to a higher total coliform count). Each total coliform and E. Coli data point in the shown in the Results section represent the geometric mean of the repeat samples. Error bars represent the $95 \%$ confidence interval of the geometric mean.

\section{Flow Rate Measurements}

The effluent flow rates were recorded for each filter after the 9 am dosing. The flow rate of each filter was calculated based on the time needed to fill a $100 \mathrm{~mL}$ graduate cylinder when there was a maximum pressure head in the filter, i.e. when the filter is full.

\section{RESULTS}

For each day that testing was completed, influent and filter effluent temperature, turbidity, total coliform and E. coli were measured. Figure 4 shows the 3:30 pm influent bacteria (total coliform and E. coli) count over the entire period of the experiments. Temperature of the dosing water to each filter at 9 am was recorded starting on day 15 , and varied from $15.5^{\circ} \mathrm{C}$ to $17{ }^{\circ} \mathrm{C}$ from day 15 to 64 , as shown in Table 3. The average temperature of the influent water over this period was $16.3^{\circ} \mathrm{C}$. 
International Journal for Service Learning in Engineering, Humanitarian Engineering and Social Entrepreneurship Vol. 10, No. 1, pp. 1-23, Spring 2015

ISSN 1555-9033
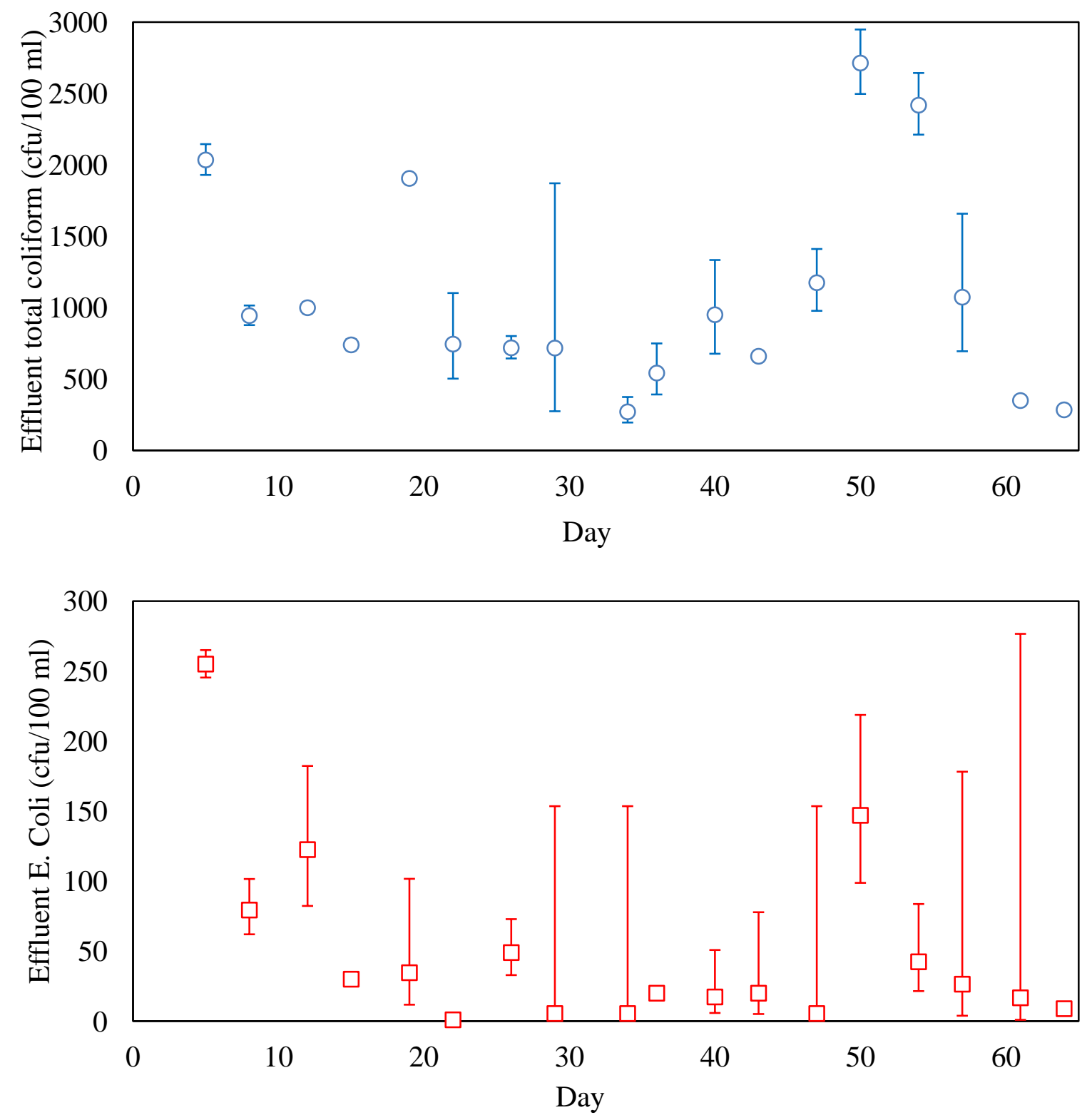

FIGURE 4

FILTER INFLUENT BACTERIAL COUNT OVER TIME. 
Table 3

TEMPERATURE OF DOSING WATER AT 9 AM

\begin{tabular}{cc}
\hline Day & 9 am dosing water temperature $\left({ }^{\circ} \mathrm{C}\right)$ \\
\hline 15 & 16 \\
19 & 16 \\
22 & 17 \\
26 & 15 \\
29 & 16 \\
34 & 17.5 \\
36 & 16.5 \\
40 & 15.5 \\
43 & 15.5 \\
47 & 16.5 \\
50 & 15.5 \\
54 & 16.5 \\
57 & 17.5 \\
61 & 17 \\
64 & 17 \\
\hline
\end{tabular}

Influent and Effluent Turbidity

The influent creek water samples had low turbidity values; average influent samples was 6.6 NTU with an extreme of 24.3 NTU on day 64 and a low of 1.76 NTU recorded on day 34 . Table 4 and Figure 5 shows the average turbidity measurements over the period of 64 days, and the turbidity of the influent and filter effluent for each day.

TABLE 4

AVERAGE EFFLUENT TURBIDITY FOR ALL SIX FILTERS, AVERAGED OVER 64 DAYS OF EXPERIMENT

\begin{tabular}{cccccccc}
\hline & Influent & CAWST & $\begin{array}{c}\text { Coarse } \\
\text { Grain-A1 }\end{array}$ & $\begin{array}{c}\text { Coarse } \\
\text { Grain-A2 }\end{array}$ & $\begin{array}{c}\text { Coarse } \\
\text { Grain-B }\end{array}$ & $\begin{array}{c}\text { Diffuser- } \\
\text { A }\end{array}$ & $\begin{array}{c}\text { Diffuser- } \\
\text { B }\end{array}$ \\
\hline $\begin{array}{c}\text { Average } \\
\text { Turbidity (NTU) }\end{array}$ & 6.60 & 1.24 & 0.45 & 0.47 & 0.75 & 0.68 & 0.87 \\
\hline
\end{tabular}




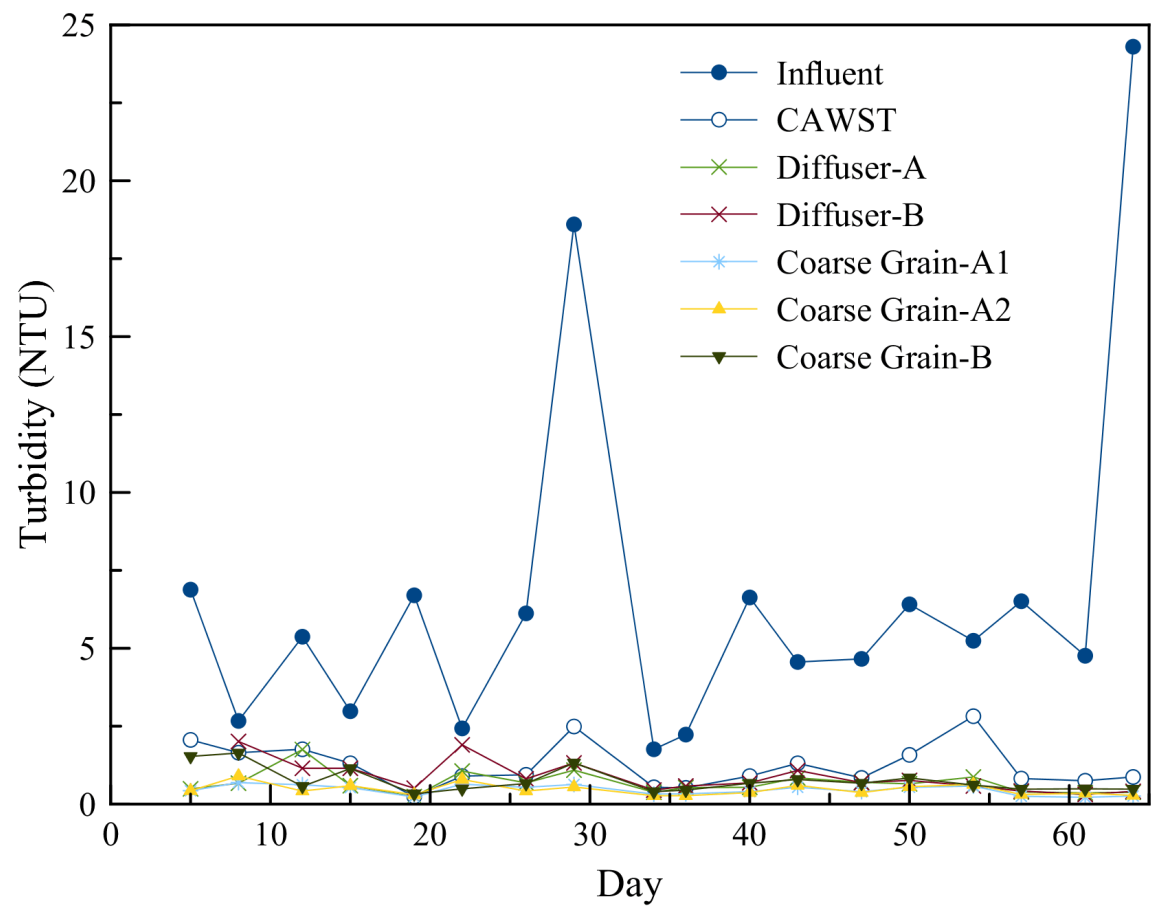

FIGURE 5

TURBIDITY OF THE INFLUENT AND FILTER EFFLUENT FOR EACH DAY.

When all filters were first constructed and installed, the flow rate of each filter was tested according to CAWST's recommended procedure. Each filter was filled to the maximum before the initial flow rate was recorded. All filters installed with fine sand (CAWST, Diffuser-A and diffuser -B filters) had an initial flow rate of $0.3 \mathrm{~L} / \mathrm{min}$, and all coarse sand filters (Coarse GrainA1, Coarse Grain-A2 and Coarse Grain B filters) had an initial flow rate of $0.75 \mathrm{~L} / \mathrm{min}$. After the installation of flow restriction valves at the outlet tubes, Coarse Grain-A1 and Coarse GrainA2 filters had an initial flow rate of $0.3 \mathrm{~L} / \mathrm{min}$ which was similar to the initial flow rates of the fine sand filters. The filters were flushed several times with creek water prior to the onset of water quality testing. When the flow rates were tested again on Day 5 of the experiment, it was observed the flow rates from each filter had changed. Most noticeably, the CAWST filter flow rate was consistently lower than the other fine sand Diffuser-A and Diffuser-B filter flow rates, as shown in Figure 6. It is possible that during the flushing cycles some sand entered and partially clogged the collection tube at the bottom of CAWST filter, thus resulting in the observed slower flow rate of the CAWST filter. From Day 5 onwards, due to the low turbidity of the source water (average turbidity of $6.6 \mathrm{NTU}$ ), no significant clogging of the filter occurred, and therefore the flow rate did not decline significantly over time. 


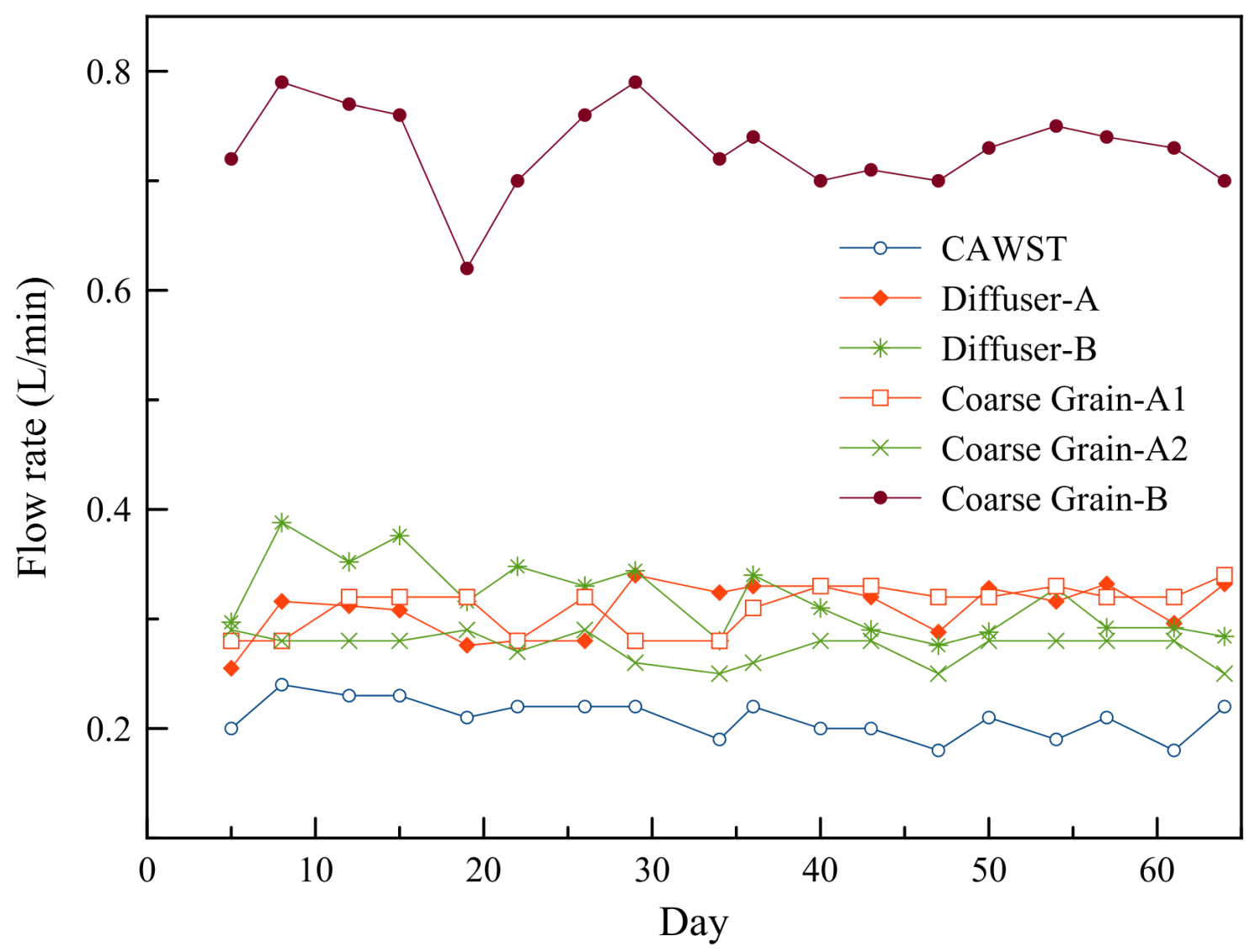

FIGURE 6

FILTER FLOW RATE OVER TIME. ALL FLOW RATES WERE MEASURED FIVE MINUTES AFTER THE END OF THE DOSING TIME, WITH MAXIMUM WATER HEAD ABOVE THE SAND LAYER.

Effect of using coarse grain sand and flow restriction valve on filter performance

The comparison of the filter effluent bacteria count (total coliform) between the CAWST filter and the coarse grain filters, with and without flow restriction valve is shown in Figure 7. Prior to Day 19, there was no clear trend as to which filter performed best. However, from Day 19 onwards the CAWST filter had lower total coliform counts compared to all the coarse grain filters, regardless of the flow rates of the coarse grain filters (i.e $Q=0.3 \mathrm{~L} / \mathrm{min}$ or $\mathrm{Q}=0.7 \mathrm{~L} / \mathrm{min}$ ). It is unclear if the biolayers in the filters were already established from Day 19 onwards. However, data from Figure 7 suggest that while the biolayers in the filters were in the process of ripening and approaching maturation, the distinction between the CAWST filters and the coarse grain filters became more apparent. The Coarse Grain-A1 and A2 filters, with flow restriction valves (average flow rate $=0.3 \mathrm{~L} / \mathrm{min}$ ) had higher effluent total coliform counts when compared to the CAWST filter, even though the flow rates of these three filters were less than the maximum flow rate of $0.4 \mathrm{~L} / \mathrm{min}$ as specified by CAWST. The Coarse Grain-B filter, without a 
flow restriction valve (average flow rate $=0.7 \mathrm{~L} / \mathrm{min}$ ), performed similarly with the Coarse Grain-A1 and A2 filters, even though its flow rate was higher than the maximum flow rate of 0.4 $\mathrm{L} / \mathrm{min}$. A similar trend was observed with the effluent E. Coli, shown in Figure 8. A spike in effluent total coliform was observed from Day 47 to Day 57. This coincided in a spike in total coliform in the influent (see Figure 4). Despite the spike, the trend of the CASWT filter showing lower effluent total coliform compared to the other coarse grain filters remains the same.

As discussed previously, slower flow rate through the filter have been observed to result in increased bacterial removal, potentially due to enhanced particle settling onto sand grains, and the increased contact time the bacteria and the sand media/biolayer ${ }^{6,7,24}$. However, results from Figure 7 and Figure 8 show that amongst the filters with the coarse grain, slower filtration flow rate in the coarse grain filters (Coarse Grain A-1, Coarse Grain A-2, flow rate $=0.3 \mathrm{~L} / \mathrm{min}$ ) did not result in better bacterial removal compared to higher filtration rates (Coarse Grain-B, flow rate $=0.7 \mathrm{~L} / \mathrm{min}$ ), for the range of flow rates examined. However, a significant difference in bacterial removal was observed between the fine grain filter (CAWST filter) and the coarse grain filters, regardless of the flow rate through the filter.

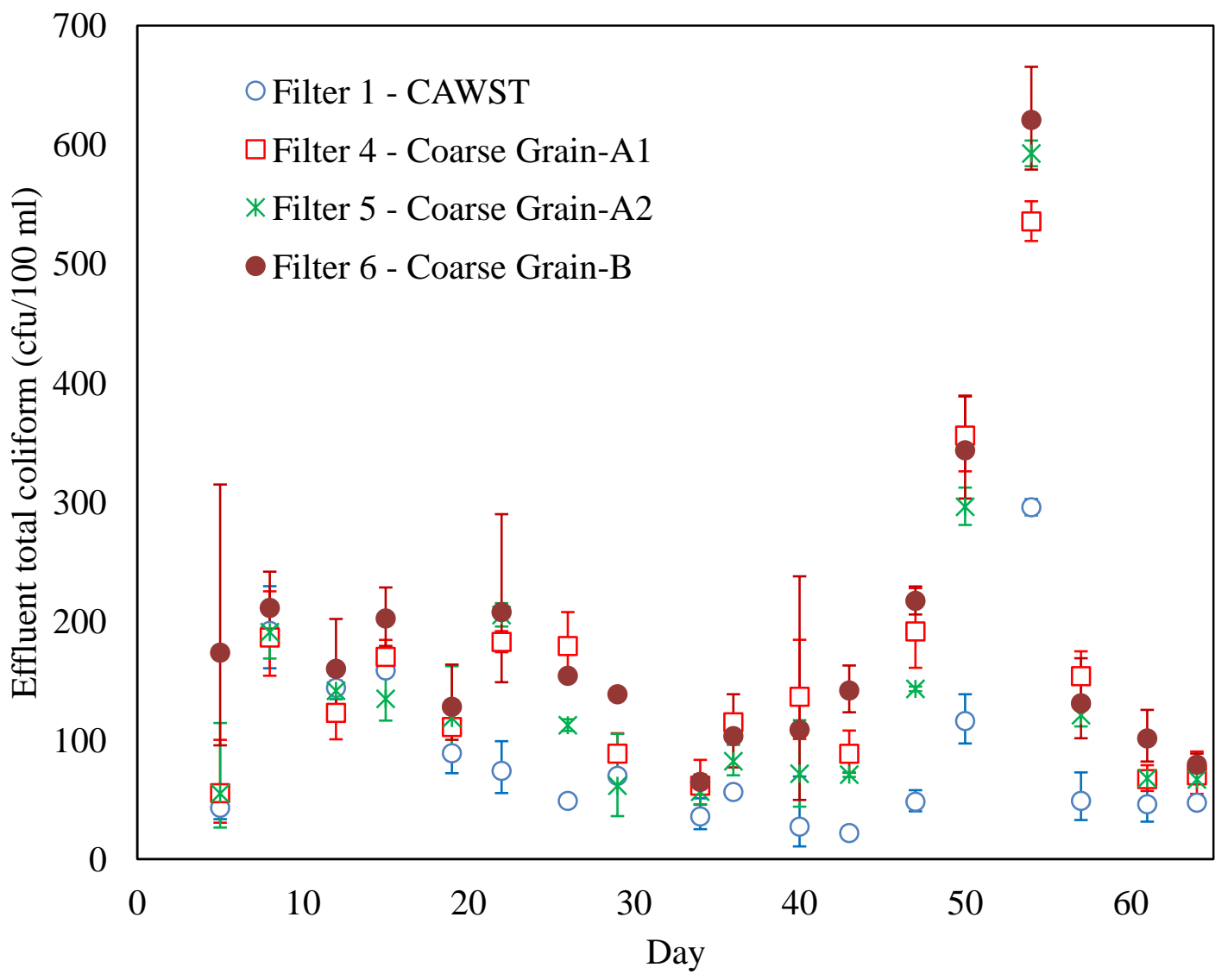

FIGURE 7

TOTAL COLIFORM COUNT OF THE EFFLUENT. 


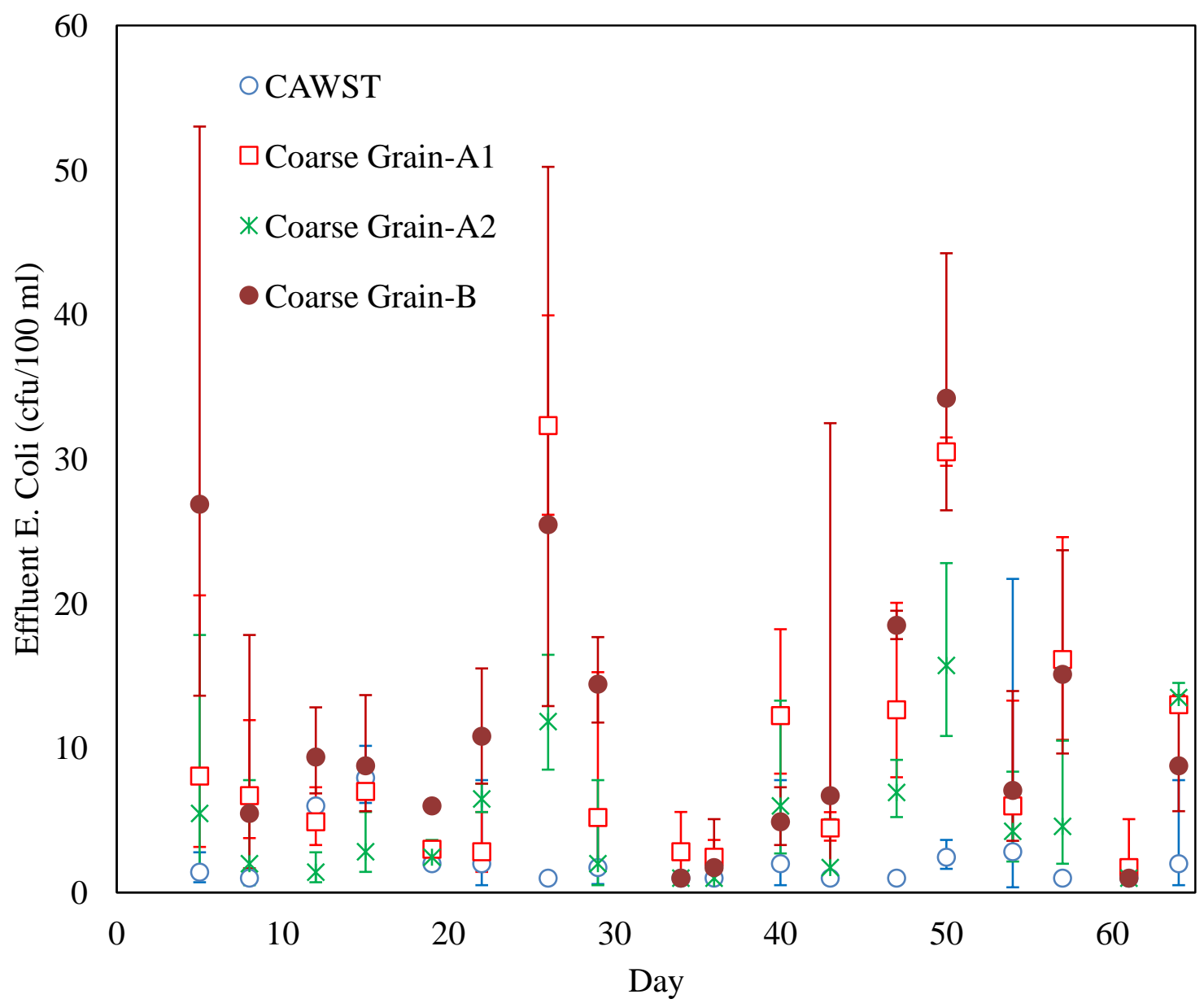

FIGURE 8

E. COLI COUNT OF THE EFFLUENT.

The potential impact of the lower flow rate in the CAWST filter $(0.2 \mathrm{~L} / \mathrm{min})$ on effluent bacteria count was examined. Figure 9 shows the comparison between the CAWST filter (average flow rate $=0.21 \mathrm{~L} / \mathrm{min}$ ), the Diffuser-A (average flow rate $=0.31 \mathrm{~L} / \mathrm{min}$ ) and Diffuser B (average flow rate $=0.33 \mathrm{~L} / \mathrm{min}$ ) filters before Day 29. Diffuser A and Diffuser B filters have the same sand media, diffuser design and operating conditions as the CAWST filter, but were operating at a slightly higher flow rate. There were no significant differences between the 3 filters during this period. As such, it is expected that the lower flow rate of the CAWST filter did not contribute significantly to lower effluent bacteria count, compared to the coarse grain filters (Figure 7 and Figure 8). 


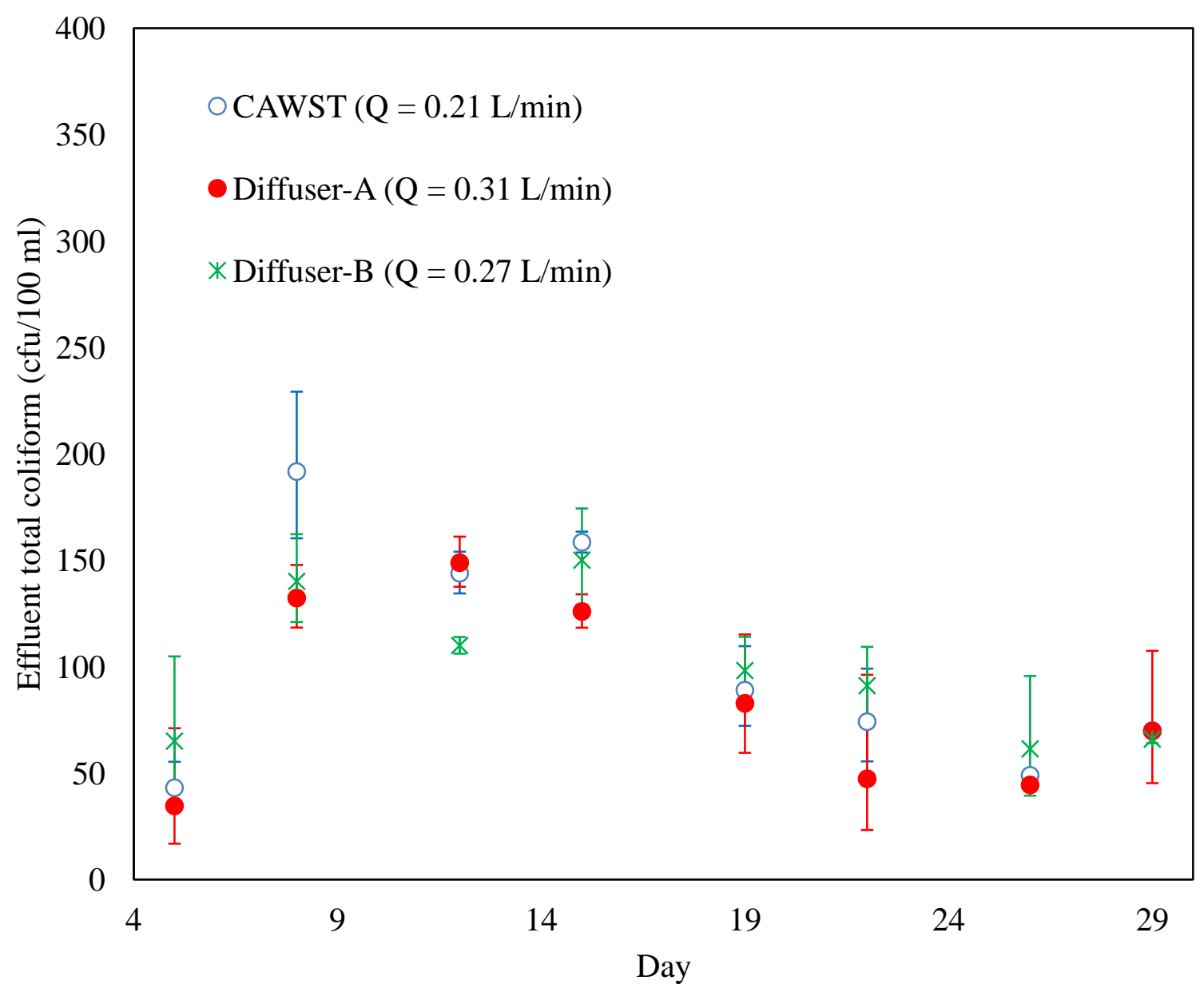

FIGURE 9

THE COMPARISON OF THE EFFLUENT BACTERIA COUNT (TOTAL COLIFORM AND E. COLI) BETWEEN THE CAWST FILTER AND DIFFUSER A AND DIFFUSER B BEFORE DAY 29.

The first objective of this study was to investigate whether it is acceptable to install a flow restriction valve in cases where the recommended sand size is not used. Results shown in Figures 7 and 8, performed under the experimental conditions described, suggest such practice is not recommended. The mechanisms of bacteria removal inside the filters which were affected by the combination of using coarse grain and flow restriction valves were not investigated in this study. It is possible that the differences between the CAWST filter and the coarse grain filter were due to the extent of residence time, or the ability to reduce the peak flow rates during initial recharge phase, and the extent of biological ripening. Further research is needed to investigate the mechanistic causes of the observed differences between the coarse grain filters (with and without flow restriction valves) and the CAWST filter, and to investigate whether the performance of the coarse grain filters will improve over a longer period of time. 


\section{Effect of diffuser design}

Prior to Day 26, Diffuser-A and Diffuser-B filters were installed with the same diffusers as the CAWST diffuser (1/8 inch hole size, 1 inch spacing). As previously shown in Figure 9, all three filters performed similarly during this period (Day 1 to Day 25). On day 26, Diffuser-A and Diffuser-B were changed with diffusers specified in Table 2. The effect of diffuser design on bacteria removal is shown in Figure 10 and Figure 11. It is observed that Diffuser-A and Diffuser-B bacteria counts were higher than that of the CAWST filter after Day 26. This suggests that diffusers installed in Diffuser-A and B filters negatively impacted filter performance. Previous studies have shown that, through visual inspection, Diffuser-A and Diffuser-B designs result in more disturbance of the top sand layer ${ }^{25}$. The observed biolayer may have a negative impact on the establishment of the biolayer needed for good bacteria removal, as well as increasing the shearing forces acting on the biolayer. Proper diffuser design is therefore shown to be important in maintaing filter bacterial removal efficiencies. The use of improperly designed diffusers, or cracked diffusers ${ }^{15}$ may negatively impact effluent water quality.

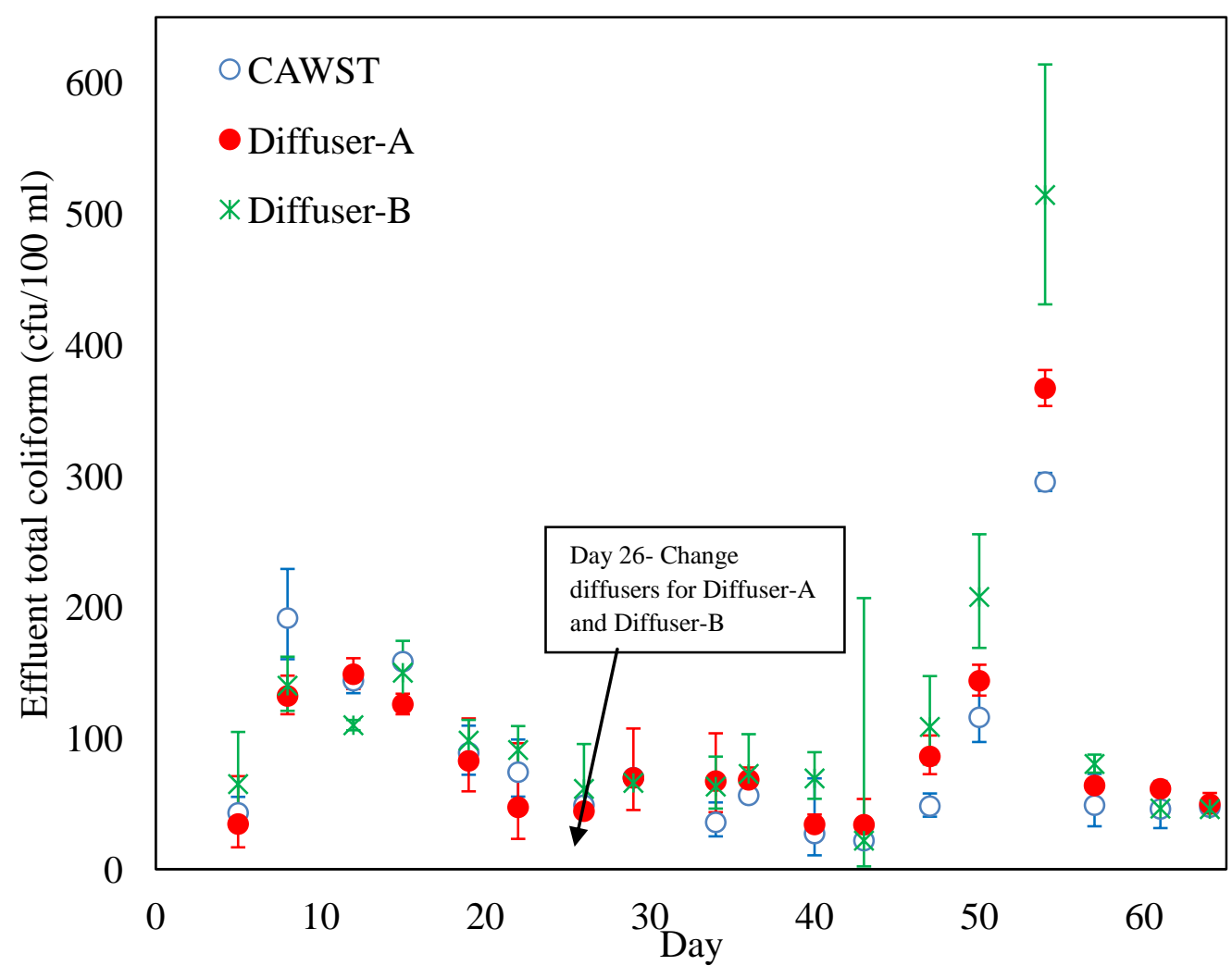

FIGURE 10

A COMPARISON OF EFFLUENT TOTAL COLIFORM BETWEEN THE CAWST FILTER, DIFFUSER-A AND DIFFUSERFILTERS. 


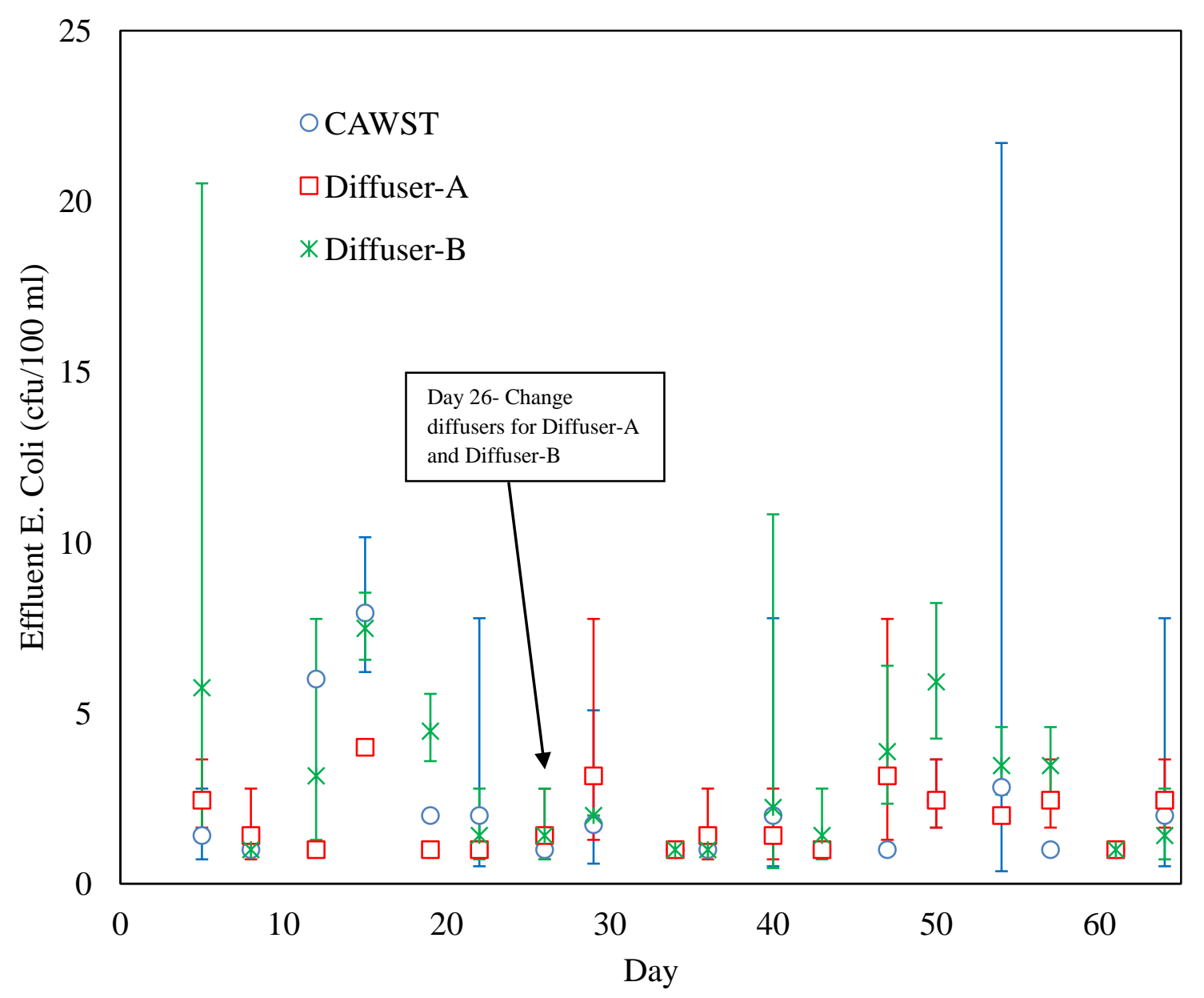

FIGURE 11

A COMPARISON OF EFFLUENT E. COLI BETWEEN THE CAWST FILTER, DIFFUSER-A AND DIFFUSER- FILTERS

Effect of Batch Residence Time

The effect of batch residence time (BRT) on bacterial removal efficiency was investigated. On Days 22, 47 and 67, the filter effluent was sampled at 9:00 am in the morning. This effluent has a BRT of 18 hours, compared to all other samples (sampled at 3:30pm) which have BRT of 6 hours. Table 5 shows the averaged percent removal and log removal of total coliform for the 6 hour and 18 hour batch residence time. Percent removal and log removal for the 6 hour BRT were calculated using the influent samples collected at 3:30 pm the same day, but corrected for the variation between the morning and afternoon sample (see discussions in section Limitation of the Batch Residence Time Study). For the 6 hour BRT, the CAWST filter had the highest percent removal and log removal of total coliform, while the Coarse Grain-B filter had the lowest percent removal and log removal of total coliform. For the 18 hour BRT, however, all filters had similar values of percent and log removal as that of the CAWST filter. This is consistent with 
observations by others ${ }^{6,20}$, where batch residence time was found to have a significant effect on the bacteria removal. The results suggest that the deficiencies caused by improper diffuser configuration (Diffuser-A and Diffuser-B filters), coarse grain size (Coarse Grain-A and Coarse Grain-B filters) can be compensated by employing a higher BRT. As such, in certain scenarios where a filter has not been design or constructed properly (i.e. using coarser grain, higher flow rate and faulty diffuser), it is recommended to use the filtered water which has the highest BRT (i.e. after the first dose in the morning) as this water will have the highest water quality compared to subsequent water dosing cycles which have a lower BRT.

TABLE 5

THE COMPARISON BETWEEN 6 HOUR BATCH RESIDENCE TIME AND 18 HOUR RESIDENCE TIME. VALUES ARE AVERAGED OVER THE 64 DAYS OF EXPERIMENTS ( $\mathrm{N}=36$ )

\begin{tabular}{ccccccc}
\hline & CAWST & Diffuser-A & Diffuser-B & $\begin{array}{c}\text { Coarse } \\
\text { Grain-A1 }\end{array}$ & $\begin{array}{c}\text { Coarse } \\
\text { Grain-A2 }\end{array}$ & $\begin{array}{c}\text { Coarse } \\
\text { Grain-B }\end{array}$ \\
\hline $\begin{array}{c}\text { 6 hour BRT } \\
\text { \% Removal }\end{array}$ & 87.3 & 85.4 & 84.4 & 77.5 & 80.2 & 74.2 \\
$\begin{array}{c}\text { 18 hour BRT } \\
\text { \% Removal }\end{array}$ & 89.1 & 87.6 & 86.3 & 90.6 & 87.8 & 84.4 \\
$\begin{array}{c}\text { 6 hour BRT } \\
\text { Log Removal } \\
\text { 18 hour BRT }\end{array}$ & 1.03 & 0.97 & 0.89 & 0.72 & 0.78 & 0.65 \\
Log Removal & 1.09 & 1.13 & 0.97 & 1.09 & 0.98 & 0.92 \\
\hline
\end{tabular}

\section{Limitations of the study}

Effect of the variability in the dosing water temperature (range of 15.5 to $17{ }^{\circ} \mathrm{C}$ ) and bacteria removal efficiency was not studied. It is possible that daily water temperature variation will have affect the time needed for the biolayer to fully mature, and the mechanisms of bacteria removal in the filters. Although the performance of each filters (i.e. total coliform count) were still comparable since each filters were dosed with the same water from the storage tank (i.e. at the same temperature, same dosing volume), further research is needed to quantify the effects of water temperature on filter performance and rates of biolayer maturation for the filters described in this paper.

Ideally, to calculate the bacterial removal efficiency of each filter, the water quality tests should be performed for the influent water which feeds each filter (i.e. 9:00 am creek influent water sample) in order to compare the influent water quality to that of the effluent collected at $3: 30 \mathrm{pm}$. However, due to logistical constraints associated with the course schedule of the undergraduate students conducting the tests, water quality tests for the filter influent at 9:00 am could not be performed. Instead, water quality tests were performed on the influent water sample at 3:30 pm, noting that this influent sample has been mixed with the influent water collected at 9:00 am. Percent removal and log removal for the 6 hour batch residence time were calculated using the influent samples collected at 3:30 pm the same day, but corrected for the variation between the morning and afternoon sample, derived from data in Table 3. Although 
this approach is not ideal, the results do provide some insight into the effects of batch residence time on filter performance.

Finally, conclusions from the present study were based on results obtained from only one type of each filter, (i.e. CAWST filter, filter of different diffuser designs, sand gradation and flow restrictions). Further studies are to be performed to test the statistical significance of the comparison of groups of each type of filters (i.e. at least 3 filters of the same type).

\section{CONCLUSIONS}

The objectives of this paper are to provide a recommendation for the CAWST filters on (1) whether the installation of a flow restriction can be justified when coarse sand is used instead of fine sand, and (2) whether different diffuser designs will impact the filtration bacterial removal efficiencies. For the range of grain size and flow rates investigated in this paper, use of sand with coarse grain size leads to reduced bacterial removal efficiencies, regardless of the flow rate through the filter. The addition of flow restrictions on filters with coarse grain size did not result in improvement in bacterial removal efficiencies. As such, in places where the sand gradation specified by CAWST cannot be met (i.e. a coarser sand is used instead of the finer sand specified), the inclination to install flow restrictions on the outlet tube is not recommended as bacterial removal efficiency of the filter may be compromised. Diffuser design was also found to have an effect on the bacterial removal efficiency. The two diffusers investigated (smaller hole size, tighter spacing) resulted in lower bacterial removal efficiencies, compared to the CAWST specified diffuser design. This suggests that diffuser design (in terms of hole size and spacing) plays an important role in dissipating energy and minimizing biolayer disturbances as water is poured into the filter. Batch residence time was found to have a significant effect on bacterial removal. The deficiencies caused by diffuser design (Diffuser-A and Diffuser-B filters), and coarse grain size (Coarse Grain-A and Coarse Grain-B filters) can compensated by a higher batch residence time.

\section{ACKNOWLEDGEMENTS}

Funding for this research provided by British Columbia Institute of Technology through the Ledcor fund is gratefully acknowledged. 


\section{REFERENCES}

1. WHO/UNICEF, Progress on sanitation and drinking water: 2010 update. World Health Organization, Geneva, 2010.

2. Mintz, E., et al., Not Just a drop in the bucket: Expanding access to point-of-use water treatment systems. American Journal of Public Health, 2001. 91(10): p. 1565-1570.

3. Sobsey, M.D., Managing water in the home: accelerated health gains from improved water supply. World Health Organization, 2002. WHO reference number: WHO/SDE/WSH/02.07.

4. Elliott, M.A., et al., Reductions of E. coli, echovirus type 12 and bacteriophages in an intermittently operated household-scale slow sand filter. Water Research, 2008. 42(1011): p. 2662-2670.

5. G. Palmateer, D.M., A. Jurkovic, Toxicant and parasite challenge of Manz intermittent slow sand filter. Enviromental Toxicology, 1999. 14: p. 217-255.

6. Jenkins, M.W., S.K. Tiwari, and J. Darby, Bacterial, viral and turbidity removal by intermittent slow sand filtration for household use in developing countries: Experimental investigation and modeling. Water Research, 2011. 45(18): p. 6227-6239.

7. Kennedy, T.J., Hernandez, E.A., Morse, A.N., Anderson, T.A., Hydraulic loading rate effect on removal rates in a biosand filter: A pilot study of three conditions. Water Air \& Soil Pollution, 2012. 223: p. 4527-4537.

8. Stauber, C., et al., Characterisation of the biosand filter for E. coli reductions from household drinking water under controlled laboratory and field use conditions. Water Science \& Technology, 2006. 54(3): p. 1-7.

9. Buzunis, B.J., Intermittently operated slow sand filtration: a new water treatment process, in Civil Engineering. 1995, University of Calgary: Calgary, Canada.

10. Vanderzwaag, J.C., et al., Field evaluation of long-term performance and use of biosand filters in Posoltega, Nicaragua. Water Quality Research Journal of Canada, 2009. 44(2).

11. Wang, H., et al., MS2 Bacteriophage reduction and microbial communities in biosand filters. Environmental Science \& Technology, 2014. 48(12): p. 6702-6709.

12. Tiwari, S.-S.K., et al., Intermittent slow sand filtration for preventing diarrhoea among children in Kenyan households using unimproved water sources: randomized controlled trial. Tropical Medicine \& International Health, 2009. 14(11): p. 1374-1382.

13. Aiken, B.A., Stauber, C.E., Ortiz, G.M., Sobsey, M.D., An assessment of continued use and health impact of the concrete biosand filter in Bonao, Dominican Republic. The American Journal of Tropical Medicine and Hygiene, 2011. 85(2): p. 309-317.

14. Prüss-Ustün, A., et al., Burden of disease from inadequate water, sanitation and hygiene in low-and middle-income settings: a retrospective analysis of data from 145 countries. Tropical Medicine \& International Health, 2014.

15. Baker, D. and W. Duke, 33 Intermittent slow sand filters for household use - a field study in Haiti. Recent Progress in Slow Sand and Alternative Biofiltration Processes, 2006: p. 278.

16. Ngai, T.K., Coff, B., Baker, D., Lentz, R., Global review of the adoption, use and performane of the biosand filter, in Slow Sand and Alternative Biofiltration Processes, N. Nakamoto, Graham, N., Collins, M.R., Gimbel, R., Editor. 2014, IWA Publishing. p. 309. 
17. Ngai, T.K.K., Global review of the adoption, use and performance of the biosand filter, in 5th Slow Sand and Alternative Biological Filtration Conference. 2014: Nagoya, Japan.

18. Dullemont, Y., et al., Removal of microorganisms by slow sand filtration. Recent Progress in Slow Sand and Alternative Biofiltration Processes. Edited by R. Gimbel, NJD Graham \& MR Collins, 2006: p. 12-20.

19. Nam, T.K., et al., Biofilm characteristics as affected by sand size and location in fluidized bed vessels. Aquacultural engineering, 2000. 22(3): p. 213-224.

20. Baumgartner, J., S. Murcott, and M. Ezzati, Reconsidering appropriate technology: the effects of operating conditions on the bacterial removal performance of two household drinking-water filter systems. Environmental Research Letters, 2007. 2(2): p. 024003.

21. McKenzie, E.R., et al., In-home performance and variability of biosand filters treating turbid surface and rain water in rural Kenya.

22. CAWST, Biosand Filter Manual: Design, Construction, Installation, Operation and Maintenance. 2009.

23. APHA, A., WEF, Standard methods for the examination of water and wastewater American Public Health Association, American Water Works Association, Water Environment Federation, 2005.

24. Huisman, L. and W. Wood, Slow sand filtration. Vol. 16. 1974: World Health Organization

25. Jones, S., Analysis of optimum diffuser plate design for CAWST's biosand filter. British Columbia Institute of Technology, Burnaby, 2013. 